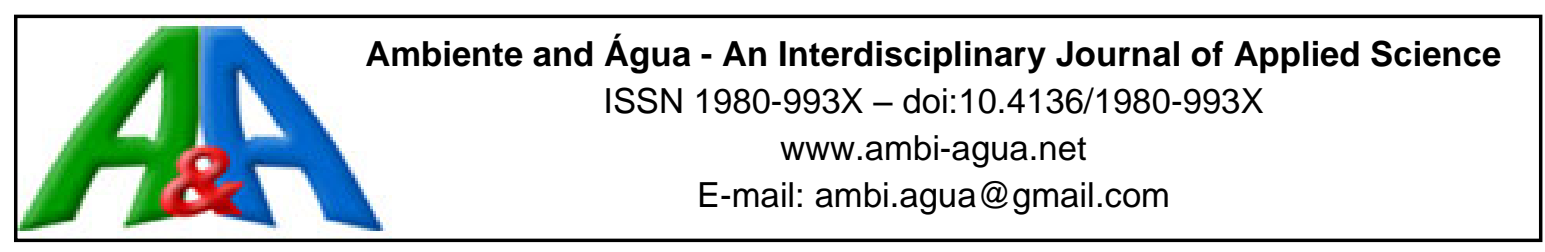

\title{
Effects of proximity to urban areas on a riparian bird community in remnant Atlantic Forest in southeastern Brazil
}

\author{
doi:10.4136/ambi-agua.2313
}

Received: 18 Nov. 2019; Accepted: 20 Dec. 2019

\begin{abstract}
Ana Cecília de Paula Lourenço; Maria Cecília Barbosa de Toledo*
Departamento de Biologia. Universidade de Taubaté (UNITAU), Av. Tiradentes, n 500, CEP: 12030-180, Taubaté, SP, Brazil. E-mail anacecilia.lourenco@ hotmail.com

*Corresponding author. E-mail: mceciliabt@gmail.com
\end{abstract}

\begin{abstract}
The goal of this study was to evaluate the effect of urban activities on the structure and composition of a bird community in riparian forests in the state of São Paulo, Brazil. The study was carried out in seven areas of remnant riparian forest where fixed points have been established to sample bird species. Richness, diversity, abundance, frequency and trophic groups were used as metrics of the bird community. At each point measurements were taken for: (1) habitat characteristics: average height of trees, number of trees above $2 \mathrm{~m}$, number of shrubs <2m and the percentage of canopy opening; (2) neighborhood characteristics: closest distance from open areas, highways, urban areas, river and floodplain to the point of observation. The observations resulted in 88 species of birds belonging to 34 families. The most representative families were Tyrannidae, Thraupidae and Picidae. The most predominant trophic groups were insectivorous (54\%), omnivorous $(11.5 \%)$ and frugivorous $(10.3 \%)$. The results obtained showed that the number of trees explained the variation in abundance, while the mean height of the trees explained variations in richness and frequency. Overall, the bird community was negatively affected by proximity of urban areas and highways. In conclusion, the community of birds in the riparian forest may be affected by the loss of trees above $2 \mathrm{~m}$ and by urbanization, leading mainly to the replacement of species belonging to specialist trophic groups by generalist species and those more adjusted to human presence.
\end{abstract}

Keywords: bird community, habitat, landscape, Paraiba do Sul River, urban activities.

\section{Efeito da proximidade de áreas urbanas sobre a comunidade de aves ripárias em remanescentes de Mata Atlântica no Sudeste brasileiro}

\section{RESUMO}

O objetivo deste estudo foi avaliar o efeito das atividades urbanas na estrutura e composição da comunidade de aves de matas ciliar rio Paraíba do Sul, estado de São Paulo, Brasil. O estudo foi realizado em sete áreas remanescentes de mata ciliar, onde foram estabelecidos pontos fixos para amostragem de espécies de aves. Riqueza, diversidade, abundância, frequência e tróficos foram utilizados como métricas estruturais da comunidade. A partir de cada ponto foram tomadas medidas quanto: (1) Características do habitat: altura média das árvores, número de árvores acima de $2 \mathrm{~m}$, número de arbustos $<2 \mathrm{~m}$ e porcentagem de abertura do dossel; (2) Características do bairro: distâncias mais próximas de áreas abertas, 
rodovias, áreas urbanas, rios e várzeas até o ponto de observação Por meio das observações foram registradas 88 espécies de aves pertencentes a 34 famílias. As famílias mais representativas foram Tyrannidae, Thraupidae e Picidae. Os grupos tróficos mais predominantes foram insetívoro $(54 \%)$, onívoro $(11,5 \%)$ e frugívoro $(10,3 \%)$. Os resultados obtidos mostraram que o número de árvores explicou melhor a variação em abundância, enquanto a altura média das árvores explicou as variações de riqueza e frequência. No geral, a comunidade de aves foi afetada negativamente pela proximidade das áreas urbanas e das rodovias. Concluindo, a comunidade de aves da mata ciliar pode ser afetada pela perda de árvores acima de $2 \mathrm{~m}$ e pela urbanização, levando principalmente à substituição de espécies pertencentes a grupos tróficos especializados por espécies generalistas e que melhor se ajustam à presença humana.

Palavras-chave: atividades urbanas, comunidade de aves, habitat, paisagem, Rio Paraíba do Sul.

\section{INTRODUCTION}

Some of the main characteristics of riparian forests are (1) linearity, the formation of corridors that can facilitate movement of individuals, allowing them to spread across the landscape or move from one forest patch to another (Rosenberg et al., 1997; Lidicker Jr., 1999) and that theoretically facilitate gene flow between forest patches and reduces rates of stochastic extinction (Fahrig and Merriam, 1994); (2) heterogeneity of habitat, because the riparian forest is an ecotone between terrestrial and aquatic ecosystems that encompass a diversity of environmental factors and processes; and (3) availability of resources such as water, nutrients, food, shade and others that are not found in adjacent environments (Gregory et al., 1991; Godinho et al., 2010; Mafia 2015). These, among other attributes of riparian forests, explain the occurrence of a high diversity of bird species even when the forest occupies a small area (Gregory et al., 1991; Silva and Vielliard, 2000; Lees and Peres, 2008).

The species that compose bird communities in riparian forests vary according to the biome, region, habitat, and season. For instance, in arid environments the riparian forest becomes a refuge to many resident bird species mainly in times of drought and a wintering place for migratory birds (Smith et al., 2008; Oneal and Rotenberry, 2009). In addition, Silva and Vielliard (2000) stated that the riparian forest bird community located in tropical forests is heterogeneous and can host endemic and migratory species that have generalist and specialist habits, and forest border species, among others. Thereby, it is important to highlight the necessity of preserving this environment for maintenance and conservation of bird communities which depend entirely depend on riparian forests, such as endemic species, or those that partially depend on them, such as migratory species, and those that use the riparian forest to rest, reproduce, eat, or obtain other resources that are available seasonally or occasionally. (Mckinney, 2002; Metzger, 2010; Mello et al., 2014).

Human occupation leads to an urbanization process that includes urban, suburban, and rural classes according to the gradient of transformations (Gianotti et al., 2016). However, this process can occur in a disorderly manner, mainly when there is no proper planning and urbanization advances into protected areas. Social inequality and the illegal housing market may lead to occupation of protective areas, such as riparian forests, creating a conflict between urban and agricultural development and the conservation of natural resources (Gonçalves and Souza 2012). Even being protected by law, riparian forests located in the urban - rural gradient are still being degraded, altering the forest structure (McDonnell and Pickett 1990), the flux of energy, nutrients, water quality, and composition and structure of the natural communities (Grimm et al., 2000; Pickett et al., 2011, Hutyra et al., 2014).

Considering that each species is affected differently by human interventions, some bird

Rev. Ambient. Água vol. 7 (supplement) - Taubaté 2019 
species are more tolerant to changes and become abundant while others are intolerant and become rare, migrate or are locally extinguished (Marini and Garcia 2005, Luther et al., 2008, Van Rensburg et al., 2009, Toledo et al., 2012). Thus, the decrease in bird species richness and an increase in the abundance and frequency of generalist and exotic species are expected effects associated with riparian forest degradation and being in close proximity to anthropic activities (Smith and Schaefer 1992, Neto and Viadana 2006, Luther et al., 2008, Oneal and Rotenberry 2009, Brummelhaus et al., 2012, Mafia 2015). Our presumption that different types of urban activities at both a local scale, such as habitat degradation, and at a landscape scale, such as agricultural activities, and expansion of cities and roads has negatively influenced the bird community when compare with natural characteristics such as the proximity of rivers and floodland (várzea). Thus, the main goal of this study was to evaluate the influence of urban activities on the composition and structure of a remnant riparian forest bird community.

\section{MATERIALS AND METHODS}

\subsection{Study area}

The study was carried out in the riparian forest of the Paraíba do Sul River located in the municipalities of Aparecida, Potim and Guaratinguetá (Table 1), state of São Paulo, Brazil. The climate of the region is classified as rainy subtropical with dry winters (Cwa) according to the KÖPPEN classification system (Rolim et al., 2007). These municipalities are located in the Atlantic Forest domain (Instituto Florestal / SP, 2016).

The Paraíba do Sul River basin is one of the most important in Brazil, as it is located between two major industrial and demographic centers, the municipalities of São Paulo and Rio de Janeiro, and supplies approximately 2,227,872 inhabitants (ANA 2016).

Table 1. Characterization of the urban region of the three counties located in the Paraíba do Sul River basin, São Paulo state, Brazil.

\begin{tabular}{|c|c|c|c|c|c|}
\hline County & $\begin{array}{l}\text { Latitude \& } \\
\text { Longitude }\end{array}$ & $\begin{array}{l}\text { Altitude } \\
\text { (M) }\end{array}$ & $\begin{array}{l}\text { Average annual } \\
\text { temperature }\left({ }^{\circ} \mathrm{C}\right)\end{array}$ & $\begin{array}{l}\text { Average } \\
\text { anual rain } \\
(\mathrm{mm})\end{array}$ & County \\
\hline Aparecida & $\begin{array}{c}22^{\circ} 50^{\prime} 49^{\prime \prime} \mathrm{S} \\
45^{\circ} 13^{\prime} 47^{\prime \prime} \\
\mathrm{W}\end{array}$ & 550 & 21.8 & 1350.9 & $\begin{array}{l}\text { Late successional forest }(2.48) \\
\text { Young secondary forest }(13)^{*}\end{array}$ \\
\hline Guaratinguetá & $\begin{array}{c}22^{\circ} 48^{\prime} 28^{\prime \prime} \mathrm{S} \\
45^{\circ} 11^{\prime} 39^{\prime \prime} \\
\mathrm{W}\end{array}$ & 530 & 21.9 & 1312 & $\begin{array}{l}\text { Late successional forest } \\
\text { (11.51) } \\
\text { Young secondary forest } \\
(9.35)^{*}\end{array}$ \\
\hline Potim & $\begin{array}{c}22^{\circ} 50^{\prime} 24^{\prime \prime} \mathrm{S} \\
45^{\circ} 15^{\prime} 19^{\prime \prime} \\
\mathrm{W}\end{array}$ & 550 & 21.8 & 1424.2 & $\begin{array}{c}\text { Late successional forest }(0.54) \\
\text { Young secondary forest } \\
(2.27)^{*}\end{array}$ \\
\hline
\end{tabular}

* INSTITUTO FLORESTAL/SP. Resultados. Mapas Municipais. SIFESP. 2016.

Seven riparian forest patches embedded in an urban matrix were chosen (Figure 1, and Table 2). The type of land use contiguous to riparian forest areas was classified as agricultural or urban.

In each area points parallel to the river were plotted with an average distance of $200 \mathrm{~m}$ from each other. In total, 35 points were established approximately $10 \mathrm{~m}$ from the edge and followed the contour of the patch. The number of points in each patch varied according to its area, shape and accessibility. To obtain the coordinates and distance of the observation points, the application "Andlocation" for Android phone was used. 


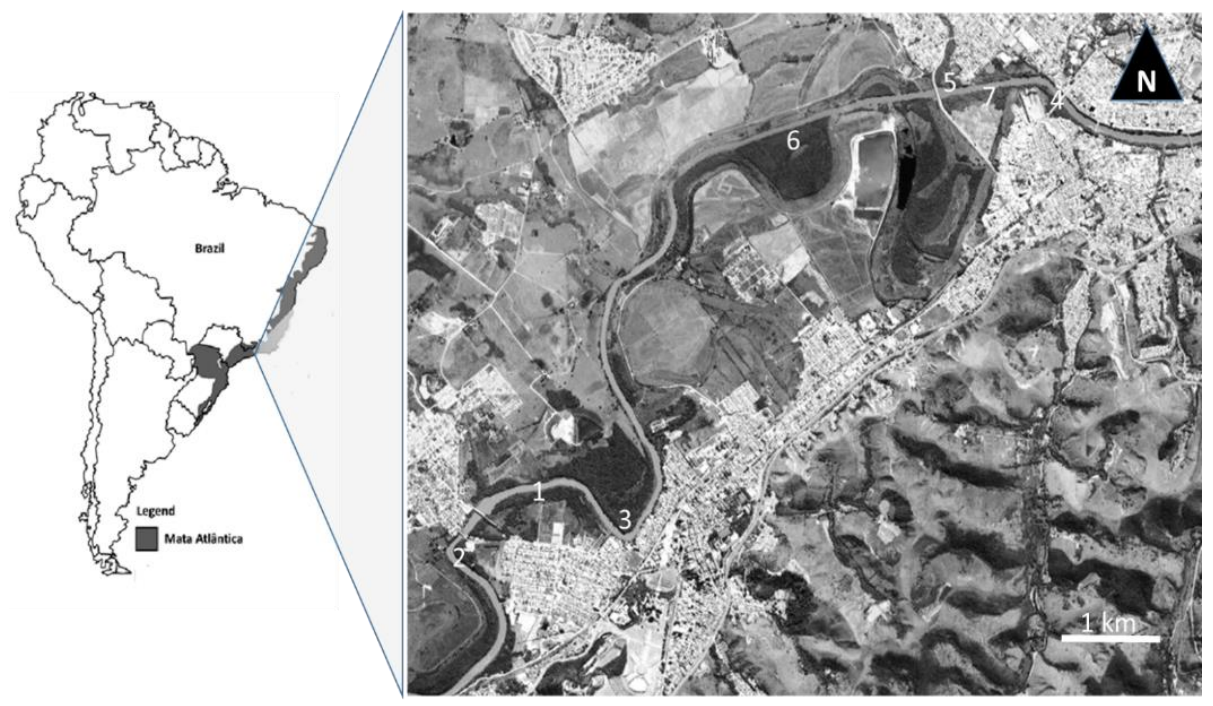

Figure 1. Localization of the study area in the southeast Brazil with presentation of the Atlantic Forest domain and in highlighted the locals where were run the surveys.

Source: Google Earth.

Table 2. Characteristics of the seven studied patches according to location (city and geographic coordinates), area (ha) and contiguous area characterization.

\begin{tabular}{|c|c|c|c|c|}
\hline ID & Lat \& Long & County & Number of points & Contiguous land use type \\
\hline 1 & $\begin{array}{l}22^{\circ} 50^{\prime} 30^{\prime \prime} \mathrm{S} \\
45^{\circ} 14^{\prime} 38^{\prime \prime} \mathrm{W}\end{array}$ & Aparecida & 8 & Degraded floodplain with shrubs and pasture. \\
\hline 2 & $\begin{array}{l}22^{\circ} 50^{\prime} 23^{\prime \prime} \mathrm{S} \\
45^{\circ} 14^{\prime} 15^{\prime \prime} \mathrm{W}\end{array}$ & Potim & 3 & Sand mine, pasture and urban area \\
\hline 3 & $\begin{array}{c}22^{\circ} 50^{\prime} 39^{\prime \prime} \mathrm{S} \\
45^{\circ} 14^{\prime} 56^{\prime \prime} \mathrm{W}\end{array}$ & Aparecida & 11 & Floodplain \\
\hline 4 & $\begin{array}{l}22^{\circ} 48^{\prime} 37^{\prime \prime} \mathrm{S} \\
45^{\circ} 11^{\prime} 49^{\prime \prime} \mathrm{W}\end{array}$ & Guaratinguetá & 2 & Urban area \\
\hline 5 & $\begin{array}{l}22^{\circ} 48^{\prime} 27^{\prime \prime} \mathrm{S} \\
45^{\circ} 12^{\prime} 29^{\prime \prime} \mathrm{W}\end{array}$ & Guaratinguetá & 2 & Urban area \\
\hline 6 & $\begin{array}{l}22^{\circ} 48^{\prime} 51^{\prime \prime} \mathrm{S} \\
45^{\circ} 13^{\prime} 16^{\prime \prime} \mathrm{W}\end{array}$ & Aparecida & 6 & Pasture and plantation \\
\hline 7 & $\begin{array}{l}22^{\circ} 48^{\prime} 33^{\prime \prime} \mathrm{S} \\
45^{\circ} 12^{\prime} 17^{\prime \prime} \mathrm{W}\end{array}$ & Guaratinguetá & 4 & Floodplain and pasture \\
\hline
\end{tabular}

\subsection{Sampling of the bird community}

The survey was performed during $4 \mathrm{~h}$ beginning immediately after sunrise, in June and July 2016 and June 2017. The field work was run during dry season due to the difficulty of access in the wet periods, when most of the patches are prone to flooding. The bird community was sampled using the point counts method - each point was visited once a month wherein the observer stayed at a point for 15 minutes recording all bird species seen and heard (Develey, 2003).

The observations were made using a 42x zoom semiprofessional camera Nikon Coolpix P510 and an audio recorder Sony ICD-PX240. The identification of the species was done using a field guide and by comparison with available databases on interactive sites such as xeno-canto and Wikiaves (Sigrist 2013, Xeno-Canto 2017, Wikiaves 2017). The list of Brazilian birds regularized by the Brazilian Ornithological Records Committee (Piacentini et al., 2015) was used as basis for scientific nomenclature.

Based on classifications of trophic groups used by Willis (1979), Sick (1997), Belton 
(2000), and Scherer et al. (2010), the species of birds were grouped as follows: insectivorous diet based mainly on the ingestion of insects; carnivorous - a diet composed essentially of live animals, such as vertebrates of various sizes and large invertebrates; frugivorous - diet composed basically of fruits; nectivorous - diet consisting especially of nectar; scavenger - diet composed of dead animals; omnivorous - diet consisting of several types of food, from fruits and arthropods to small vertebrates; granivorous - diet based on the ingestion of seeds; piscivorous - diet consisting mainly of fish; and herbivorous - those who eat plants.

The classification according to habitat use was based on observations of species occurrence in the riparian forest during the period of study, and were divided into arboreal - species with forest habits almost always seen in the crown of the trees; forest edge (strip of $2 \mathrm{~m}$ from the open area); open area (pastures and plantations, but was registered inside the patch); wetland (river bank, floodplain or swamp); and canopy (species that were always seen perched on tree tops, mainly in emergent trees).

\subsection{Variables analyzed}

For the description of bird community structure, richness, absolute abundance (total number of individuals per species), frequency (obtained from number of points that bird was observed by total number of points), Shannon index ( $\left.\mathrm{H}^{\prime}\right)$, evenness, and dominance (Happer 1999) were analyzed.

At each point three visits were made, one in each study month. In order to avoid pseudoreplication, patches and sampling points were randomly chosen, and during this time an average of three points were visited per day. The characterization was done at each point according to two scales: (1) habitat and (2) neighborhood.

Habitat characteristics: in a radius of $5 \mathrm{~m}$ from the sampling point we quantified average height of trees, number of trees $>2 \mathrm{~m}$ high, number of shrubs $<2 \mathrm{~m}$ in height and percentage of canopy opening. To estimate the height of the trees a visual parameter was using a $2 \mathrm{~m}$ ruler parallel to the trunk of each tree from the ground. The ruler was also used to demarcate, approximately, the radius around the point for quantification of trees and shrubs. Photos using a cellphone and fisheye lens $180^{\circ}$ (Daite, model 10x) were taken. Each photo was analyzed with Image J software (Abràmoff et al., 2004) counting area with vegetation by total area to determine the percentage of canopy cover.

Neighborhood characteristics: measurements were taken from the observation point considering the closest distances (from the edge of the patch) in meters to open areas (pasture and agriculture), urban area (cities or built-up areas), highways (paved with asphalt or concrete and with two or more lanes), floodplains and rivers. All distances were obtained through the ruler tool available in Google Earth.

\subsection{Data analyses}

The D'Agostino test was run before all analyses to check the normal distribution of the data. We classified each point as urban or agriculture according to nearest type of land use. Thus, we compared urban points $(\mathrm{n}=11)$ versus agricultural $(\mathrm{n}=16)$ ones for richness, total abundance ( $\sum$ of the number of individuals of all species observed), total frequency ( $\sum$ of the frequency of each species observed at one point; for example, if at one point three species were observed, and one of these occurred at 30 points out of a total of $36(\mathrm{fr}=30 / 36=0.83$ ), another at $3 / 36=0.083$ and the third at $16 / 36=0.36$ the frequency value at the point was 1.27 ). An unpaired t- test was used for comparisons at each point. To analyze the collinearity among explanatory variables (habitat characteristics: average height of trees, number of trees above $2 \mathrm{~m}$, number of shrubs $<2 \mathrm{~m}$ and percentage of canopy opening, and neighborhood characteristics: distances in meters from open areas, highways, urban areas, floodplains and rivers) the Pearson's linear correlation was used, and variables with $r>0.5$ were excluded. 
However, the results showed no significant correlation thus eliminating the possibility of collinearity among explanatory variables. Linear regression using $\mathrm{R}^{2}$ and $\mathrm{p}$-values for model validation was conducted to describe the relationship between dependent (richness, abundance and frequency) and explanatory variables (habitat characteristics: average height of trees, number of trees above $2 \mathrm{~m}$, number of shrubs $<2 \mathrm{~m}$ and percentage of canopy opening, and neighborhood characteristics: distances in meters from open areas, highways, urban areas, floodplains and rivers). The correlation and regression analyses were performed in Prism graphpad $\mathrm{V}$, with a significance level of $\mathrm{p}<0.05$.

The aggregate effect of the explanatory variables on the bird species was analyzed using Canonical Correspondence Analysis - CCA, using abundance values of the registered species. Principal Component Analyses - PCA - was used to reduce the number of variables used in the $\mathrm{CCA}$; thus, variables with eigenvalues $<0.5$ were excluded. All multivariate analyses were run in PAST 3.22.

\section{RESULTS AND DISCUSSION}

In total, 88 species from 34 different families were inventoried in the study area (Appendix 1). The descriptive indices of the community were: Shannon index $\left(\mathrm{H}^{\prime}\right)=3.67$, evenness $=0.45$, and dominance $=0.04$. Compared with the Wikiaves website (Wikiaves 2018), our study showed that these bird species in the riparian forest represented $65.7 \%$ of the bird community. The families with the highest number of species were Tyrannidae $(n=19)$, Thraupidae $(n=9)$, and Picidae $(\mathrm{n}=6)$. The most abundant species during observation periods were Pygochelidon cyanoleuca (Vieillot, 1817) (Blue-and-white Swallow), Coereba flaveola (Linnaeus, 1758) (Bananaquit), Pitangus sulphuratus (Linnaeus, 1766) (Great Kiskadee), and Troglodytes musculus Naumann, 1823 (Southern House Wren). A total of 17 species were represented by just one individual. Most species were classified as arboreal and/or endemic to humid areas (observed at the forest edge close to floodplains and river banks), and were more observed at points located in study areas 1 and 6 . Four species were observed at most of the sampling points, of which all were native; Coereba flaveola (Linnaeus, 1758) and Pintangus sulphuratus (Linnaeus, 1766) were detected at $93 \%$ of the sampling points; Troglodytes musculus (Naumann, 1823) and Pygochelidon cyanoleuca (Vieillot, 1817) were detected at $89 \%$ and $79 \%$ of the sampling points, respectively. These four species are commonly observed in heavily urbanized areas (Toledo et al 2012). During the study period only one exotic Passer domesticus (Linnaeus, 1758) (House Sparrow) and one endangered species Amadonastur lacernulatus (Temminck, 1827) (White-necked Hawk) were recorded.

The percentage of species registered in each trophic group was insectivores (54\%), omnivores $(12.6 \%)$, frugivores $(10.3 \%)$, granivores $(5.7 \%)$, piscivores $(5.7 \%)$, carnivores (4.6\%), nectarivores $(4.6 \%)$, herbivores $(1.1 \%)$, and scavengers $(1.1 \%)$. Tyrannidae represented the family with the highest number of species, which is typical for the Neotropical region, and might explain the predominance of the species in this family, including Pitangus sulphuratus (Sigrist 2013). In addition, many Tyrannids are able to adjust to a wide variety of environments, including those affected by urbanization (Aleixo \& Vielliard 1995, Sick 1997, Almeida et al. 1999, Anjos et al. 2007). Most of the Tyrannid species detected in our study belonged to insectivorous and omnivorous trophic groups. The prevalence of insectivores and omnivores was expected, because are common in tropical regions where insects are always available (Sick 1997). These groups were also observed in other studies carried out in Brazil, including both forest remnants and protected areas (Blamires et al. 2001, Telino-Júnior et al. 2005, Donatelli et al. 2007). In other cases, where studies were carried out in urban green areas (such as parks), omnivores dominated over other trophic groups (Argel-de-Oliveira 1995, Villanueva \& Silva 1996, Valadão et al., 2006, Scherer et al., 2010). This dominance of omnivores was probably

Rev. Ambient. Água vol. 7 (supplement) - Taubaté 2019 
due to their lack of food preferences, allowing them to forage on food resources that are not subject to seasonal variations, including human leftovers (Scherer et al., 2010).

For habitat groups, the most recorded species were classified as arboreal $(n=28)$, followed by wetlands $(n=17)$. These species are almost exclusively recorded in the canopy of trees and, therefore, are found in riparian forests, which serve as refuges in urbanized environments (Silva \& Vielliard, 2000, Luther et al., 2008, Oneal \& Rotenberry, 2009). This refuge hypothesis is reinforced by the registered presence of the species Amadonastur lacernulatus, which is endemic to the Atlantic Forest and is considered endangered due to the loss of habitat due to human construction and lead contamination (Plaza et al. 2018, Sarasola 2018). Amadonastur lacernulatus uses tall trees to build its nest, and is commonly observed in coastal areas, and is rarely observed above $900 \mathrm{~m}$ (Sigrist 2013). Thus, riparian forests might be important for species that use wide territories, such as top predators. In addition, most species that were only observed once were edge of forest or species endemic to wetlands, including Myiarchus swainsoni (Cabanis \& Heine, 1859) and Nycticorax nycticorax (Linnaeus, 1758). This finding demonstrates the importance of these environments for conserving species susceptible to change, including the removal of trees for human activities (Silva \& Vielliard, 2000, Luther et al., 2008, Oneal \& Rotenberry, 2009, Sigrist, 2013).

The results of the comparisons using richness, abundance, and frequency were evaluated in relation to the closest land-use type (agricultural or urban) to the observation point (Figure 2). A non-significant result was obtained for $(\mathrm{t}=0.318, \mathrm{p}=0.75285)$ between the two land-use types. On the other hand, abundance $(\mathrm{t}=2.7185 ; \mathrm{p}=0.01)$ and frequency $(\mathrm{t}=4.4424 ; \mathrm{p}=0.000)$ were significantly different and were higher at the points closest to urban areas. These results corroborate our hypothesis that urbanization influences the structure of the bird community. Other works documented that in a rural-urban gradient changes in the structure of the bird community are observed (Clergeau et al., 1998; Garaffa et al., 2009) such as increase in abundance and frequency of generalist species (McDonnell \& Pickett, 1990; Marzluff, 2001; Pickett et al., 2011). We observed that generalist and opportunistic species exhibited high values of abundance, which might be explained by their close proximity to urban environments (Smith \& Schaefer 1992, Neto \& Viadana 2006, Luther et al., 2008, Oneal \& Rotenberry, 2009, Brummelhaus et al., 2012, Kale et al., 2012). For example, Passer domesticus, Pitangus sulphuratus, and Thraupis sayaca are already strongly adjusted to urban environments, and are abundant in cities (Amâncio et al., 2008, Sigrist, 2013).

Linear regression analysis showed that abundance and frequency were the most sensitive parameters to changes in habitat as well as in landscape. Between the habitat and landscape variables, richness, abundance, and frequency showed that the average height of trees explained $<15 \%$ variation in richness and frequency, while the number of trees explained $22 \%$ of abundance. The landscape variables, distance to urban areas and highways, had stronger power in explaining variation in the abundance and frequency of birds. The number of trees, distance to highways, and urban areas were negatively correlated with the abundance and frequency of bird species. In comparison, the average height of trees and number of shrubs $<2 \mathrm{~m}$ were positively correlated with species richness and frequency (Table 3 ).

The increase in abundance of a few species is generally observed in highly urbanized environments when compared to natural environments (Gagné \& Fahrig 2011). In urbanized environments, native specialist species are replaced by generalist native or exotic species. Consequently, species richness cannot change significantly. In comparison, the abundance and frequency of species may be the better parameters to identify changes in community structure (Marini \& Garcia 2005, Luther et al. 2008). The PCA results corroborate those obtained in the regression analysis. 

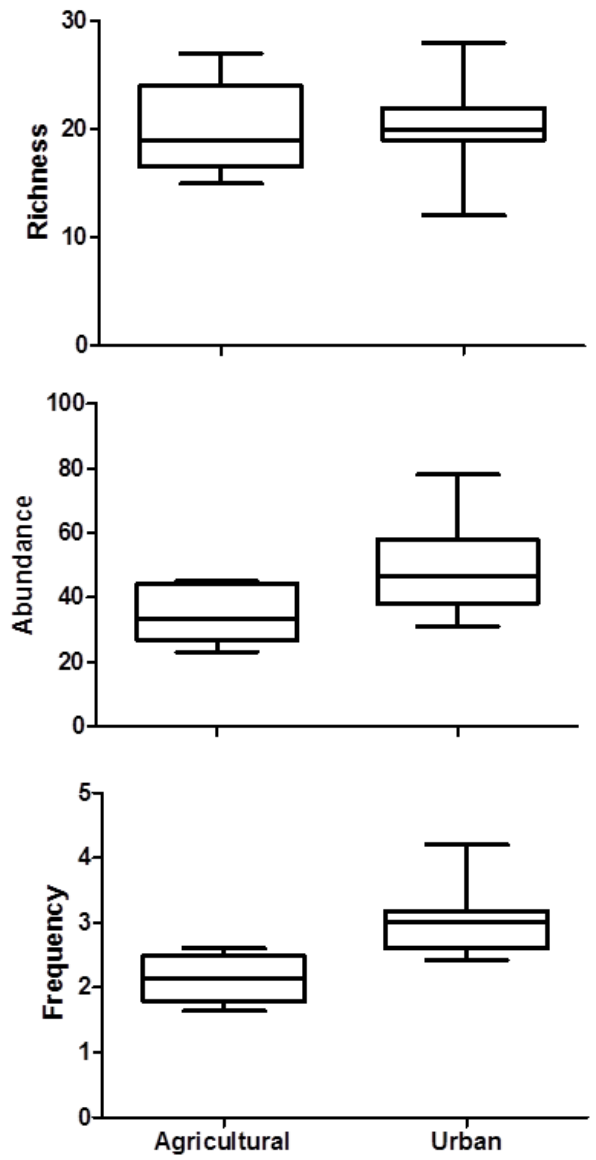

Figure 2. Average, maximum and minimum values, and standard deviation of variation in richness, abundance and frequency between rural and urban land use.

Table 3. Results of linear regression analysis for local and neighborhood variables with abundance, richness, and frequency.

\begin{tabular}{lccc}
\hline Variables & Richness & Abundance & Frequency \\
\hline Local & \multicolumn{3}{l}{} \\
\hline Number of trees $>2 \mathrm{~m}$ & 0.048 & $-0.22^{* *}$ & -0.055 \\
Number of shrubs $<2 \mathrm{~m}$ & 0.172 & -0.24 & $0.135^{*}$ \\
Height of trees & $-0.14^{*}$ & -0.091 & $-0.123^{*}$ \\
Canopy opening & 0.045 & $-0.153^{*}$ & -0.008 \\
\hline \multicolumn{3}{l}{} \\
\hline Distance to open areas & 0.001 & 0.004 & $0.158^{*}$ \\
Distance to floodplain & 0.139 & $-0.129^{*}$ & 0.016 \\
Distance to highways & 0.143 & $-0.260^{* *}$ & $-0.257^{* *}$ \\
Distance to urban area & 0.002 & $-0.173^{* *}$ & $-0.398^{* * *}$ \\
Distance to the river & 0.027 & $-0.134^{*}$ & 0.064 \\
\hline
\end{tabular}

$* \mathrm{p}<0.05 * * \mathrm{p}<0.01 * * * \mathrm{p}<0.001$ 
PCA analyses showed that the number of trees above $2 \mathrm{~m}$ and distance to highways, urban areas, floodplains, and rivers explained more than $50 \%$ of the observed variation (eigenvalues $>0.5$; Table 4). These parameters were therefore included in the CCA analysis with the PC1 variable and were the variables included in the PCA analysis. The PC1 eigenvalue was 3.118 and explained more than $89.9 \%$ of the variation. The CCA analysis showed the relationship between the observation points and PC1 and variables that contributed with greater variation (Figure 3). The closer to the river, the further away from urban areas and highways, and the more trees present at the observation points, the greater the chances of observing the rarest and most forest-dependent species (Figure 4), and the greater the chances of maintaining a better and more conserved community of birds.

Table 4. First and second principal component weight values obtained from Principal Component Analyses - PCA - for local and neighborhood variables.

\begin{tabular}{|c|c|c|c|}
\hline & Variables & PC 1 & PC 2 \\
\hline \multirow{4}{*}{ 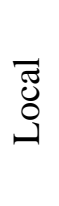 } & Number of trees $>2 \mathrm{~m}$ & 0.519 & -0.289 \\
\hline & Number of shrubs $<2 \mathrm{~m}$ & 0.167 & 0.019 \\
\hline & Height of trees & -0.111 & 0.283 \\
\hline & Canopy opening & -0.262 & -0.248 \\
\hline \multirow{5}{*}{$\begin{array}{l}\overrightarrow{0} \\
0 \\
\frac{0}{0} \\
0 \\
\frac{0}{0.0} \\
\overrightarrow{0} \\
z\end{array}$} & Distance to open areas & -0.203 & -0.243 \\
\hline & Distance to floodplain & 0.542 & -0.155 \\
\hline & Distance to highways & 0.988 & 0.080 \\
\hline & Distance to urban area & 0.979 & -0.149 \\
\hline & Distance to the river & 0.648 & 0.719 \\
\hline
\end{tabular}

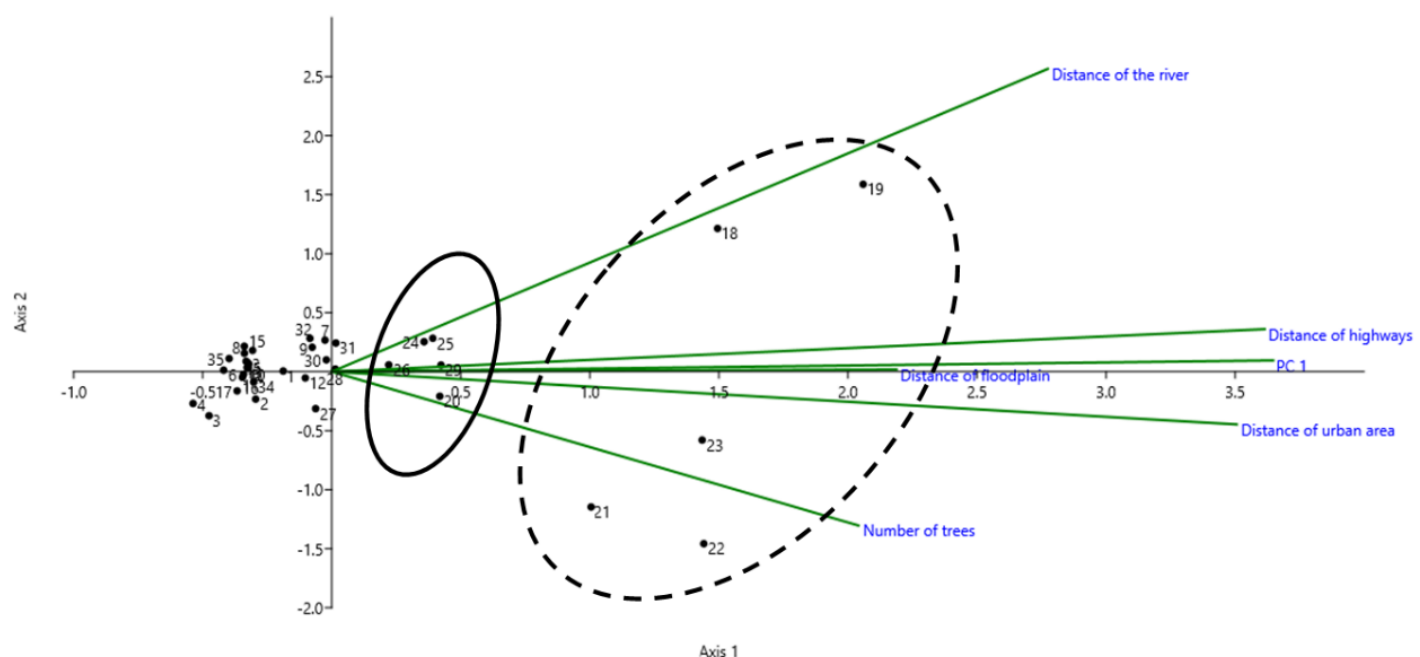

Figure 3. Graphical representation of the canonical correspondence analysis between observation points and the main analyzed variables; namely, distance to the river, distance to urban areas, distance to public roads, distance to the floodplains, and number of trees. Blue circle: observation points in area 3. Blue circle: observation points in area 6.

CCA (Figure 3) also showed that species with forest habits such as Manacus manacus and Florisuga fusca were present at points furthest away from highways, urban areas and rivers. The opposite trend was obtained for generalist and/or opportunistic habit species such as Passer 
domesticus and Pitangus sulphuratus, which were negatively correlated to these variables since these species are closely linked to the urban environment. Arboreal species such as Conirostrum speciosum were negatively correlated to the percentage of canopy opening. Birds that are always detected close to aquatic environments were negatively correlated (the smaller the distance, the greater the abundance) with distance to the river. Examples of such species included Furnarius figulus and Nannopterum brasilianus, which were consistently detected in vegetation closest to the river.

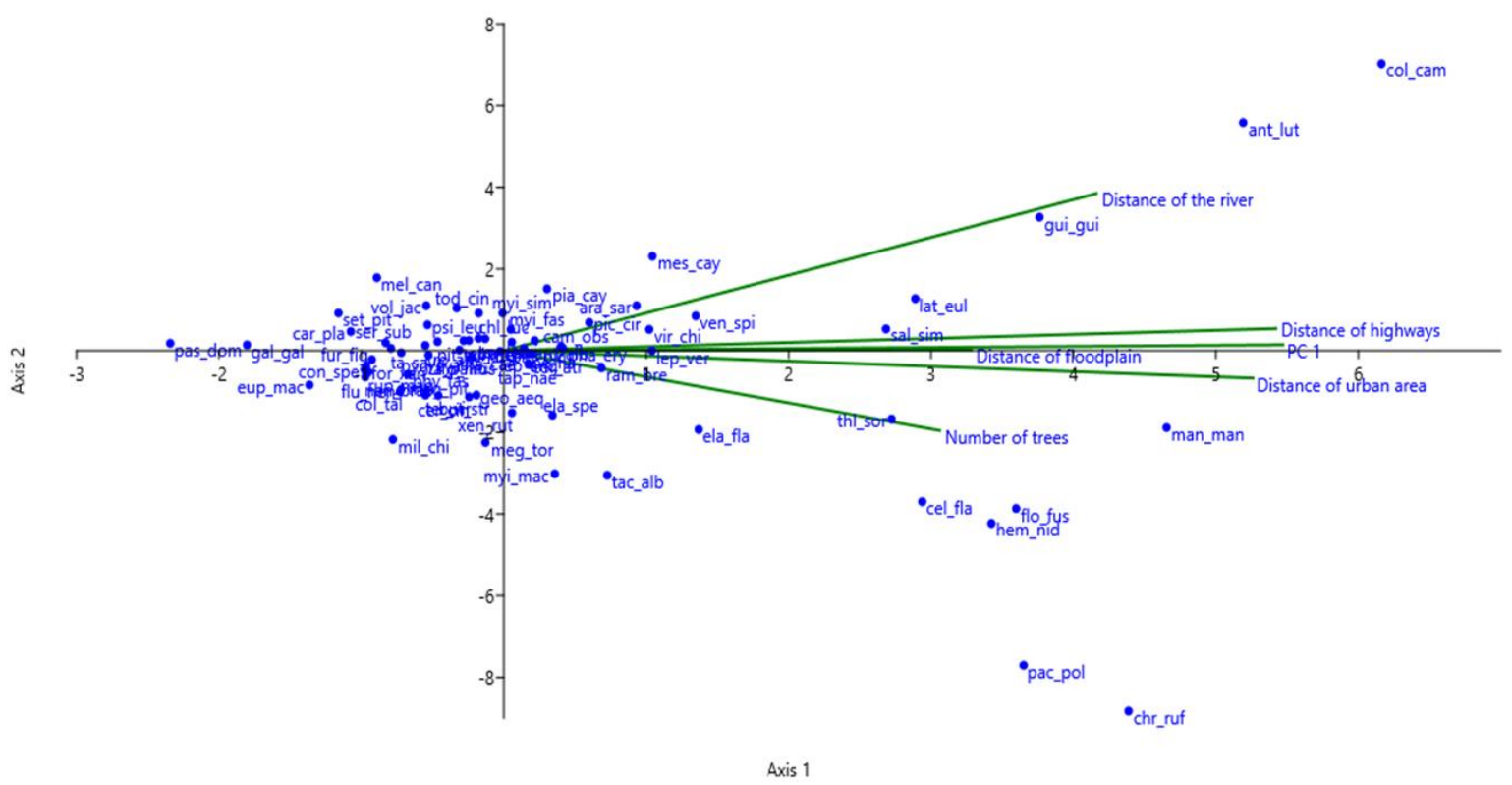

Figure 4. Graphical representation of the canonical correspondence analysis between observed bird species and the main variables analyzed; namely, distance to rivers, distance to urban areas, distance to public roads, distance from the floodplain, and number of trees.

In general, our results provide evidence for the effects of urbanization. For instance, species like Hemitriccus nidipendulus, Manacus manacus, and Florisuga fusca had abundance values that were inversely proportional to the distance of urban areas and/or public roads. In other words, the points closest to urban environments supported a higher abundance of generalist species. That is, abundance and frequency differed between the observation points located near rural and urban environments. Studies carried out by Saab (1999) and Kennedy et al. (2010) in the United States of America (USA) and Jamaica, respectively, showed that neighborhood type had the greatest influence on the bird communities of remaining areas. Saab (1999) showed that the remaining areas close to natural environments had high richness and a greater frequency of specialist species. In comparison, in areas where the surrounding environment had been altered by man, exotic, parasitic, and nest predator species were more common (Saab, 1999). Kennedy et al. (2010) showed that the abundance, richness, and composition of the bird community depends on the type of surrounding environment. For instance, agricultural environments support more conserved bird communities than peri-urban environments (Kennedy et a.,1 2010).

Species for which only one individual was observed were more frequently detected at points located in the largest areas (1 and 6) that had very distinct characteristics (see Table 1). Points located in area 1 were characterized by the typical linear arrangement of the riparian forest, facilitating its use as an ecological corridor (SMA/SP 2014). The $6^{\text {th }}$ area was circular in shape and was surrounded by rural areas, which reduce human interference (McKinney 2002). At intermediate levels (where the natural and anthropic environments had similar proportions), the number of species was higher. At sites, where urbanization is high, species richness 
declines, with a significant loss of species that are less tolerant to urban environments (Gagné \& Fahrig, 2011, Ortega-Álvarez \& Macgregor-Fors, 2011, Brummelhaus et al., 2012).

\section{CONCLUSIONS}

In general, our results show that the effects of surrounding urban activities were more significant than habitat effects, with only the points located in areas greater than 10 ha, far from urban areas, and with emergent trees maintaining a better-conserved and well-structured bird community, in terms of composition, abundance, and frequency. Our results highlight the importance of conserving large areas with more structured vegetation, which provides important habitat diversity for the maintenance of bird communities in riparian forest remnants. Rare and endemic species could be used as a reference to identify these areas that could be considered priority for conservation. Unfortunately, surrounding areas of the riparian forest are constantly being degraded or subjected to various types of anthropic interference, particularly urbanization. Thus, management actions can be proposed to improve conservation of priority areas, for example use of buffer strips to reduce the impacts of border areas.

\section{REFERENCES}

ABRÀMOFF, M.D.; MAGALHÃES, P.J.; RAM, S.J. Image processing with ImageJ. Biophotonics international, v. 11, n.7, p.36-42, 2004.

ANA - AGÊNCIA NACIONAL DE ÁGUAS. Bacia do rio Paraíba do Sul. Disponível em: http://www2.ana.gov.br/Paginas/servicos/outorgaefiscalizacao/Rio Paraiba doSul.aspx. Acesso em: 28 jul. 2016.

ALEIXO, A.; VIELliARD, J. M. E. Composição e dinâmica da avifauna da mata de Santa Genebra, Campinas, São Paulo, Brasil. Revista Brasileira de Zoologia, v. 12, n. 3, p. 493-511, 1995. DOI: 10.1590/S0101-81751995000300004.

ALMEIDA, M. E. C.; VIELLIARD, J. M. E.; DIAS, M. M. Composição da avifauna em duas matas ciliares na bacia do rio Jacaré-Pepira, São Paulo, Brasil. Revista Brasileira de Zoologia, v. 16, n. 4, p. 1087-1098, 1999.

AMÂNCIO, S.; MELO, C.; SOUZA, V. B. de. Columba livia e Pitangus sulphuratus como indicadoras de qualidade ambiental em área urbana. Revista Brasileira de Ornitologia, v. 16, n. 1, p. 32-37, mar. 2008.

ANJOS, L. dos; VOLPATO, G. H.; LOPES, E. V.; SERAFINI, P. P.; POLETTO, F.; ALEIXO, AThe importance of riparian forest for the maintenance of bird species richness in an Atlantic Forest remnant, southern Brazil. Revista Brasileira de Zoologia, v. 24, n. 4, p. 1079-1086, 2007. DOI: 10.1590/S0101-81752007000400027

ARGEL-DE-OLIVEIRA, M. M. Aves e vegetação em um bairro residencial da cidade de São Paulo (São Paulo, Brasil). Revista Brasileira de Zoologia, v. 12, n. 1, p. 81-92, 1995. DOI: 10.1590/S0101-81751995000100011

BELTON, W. Aves do Rio Grande do Sul: Distribuição e biologia. São Leopoldo: Unisinos, 2000. 584p.

BLAMIRES, D.; VALGAS, A. B.; BISPO, P. Estrutura da comunidade de aves da Fazenda Bonsucesso, município de Caldazinha, Goiás, Brasil. Tangara, v. 1, n. 3, p. 101-113, 2001. 
BRUMMELHAUS, J.; WEBER, J.; PETRY, M. V. A influência da fragmentação da mata ciliar sobre a avifauna na Bacia Hidrográfica do Rio Caí, Rio Grande do Sul. Neotropical Biology and Conservation, v. 7, n. 1, p 57-66, jan/abr. 2012. DOI: 10.4013/nbc. 2012.71 .08

CLERGEAU, P.; SAVARD, J.P.L.; MENNECHEZ, G.; FALARDEAU, G. Bird abundance and diversity along an urban-rural gradient: a comparative study between two cities on different continents. The Condor, v. 100, n. 3, pp.413-425, 1998.

DAMI, F.D.; MWANSAT, G.S.; MANU, S.A. The effects of forest fragmentation on species richness on the Obudu Plateau, south-eastern Nigeria. African Journal of Ecology, v. 51, p. 32-36, 2012.

DEVELEY, P. F. Métodos para estudos com aves. In: CULLEN L.; RUDRAN, R.; VALLADARES-PADUA C. Manejo de estudos em biologia da conservação e manejo da vida silvestre. Curitiba, URPR, 667 p. 2003

DONATELLI, R. J. Análise comparativa da assembleia de aves em dois remanescentes florestais no interior do Estado de São Paulo, Brasil. Revista Brasileira de Zoologia, v. 24, n. 2, p. 362-375, 2007. DOI: 10.1590/S0101-81752007000200015

FAHRIG, L.; MERRIAM, G. Conservation of Fragmented Populations. Conservation Biology, v. 8, n. 1, p. 50-59, 1994. DOI: 10.1046/j.1523-1739.1994.08010050.x.

GAGNÉ, S. A.; FAHRIG, L. Do birds and beetles show similar responses to urbanization? Ecological Applications, v. 21, n. 6, p. 2297-2312, 2011. DOI: 10.1890/09-1905.1

GARAFFA, P.I.; FILLOY, J.; BELLOCQ, M.I. Bird community responses along urban-rural gradients: does the size of the urbanized area matter? Landscape and Urban Planning, v. 90, n. 1-2, p.33-41, 2009.

GIANOTTI, A.G.S.; GETSON, J.M.; HUTYRA, L.R.; KITTREDGE, D.B. Defining urban, suburban, and rural: a method to link perceptual definitions with geospatial measures of urbanization in central and eastern Massachusetts. Urban ecosystems, v. 19, n. 2, p.823$833,2016$.

GODINHO, C.; RABAÇA, J. E.; SEGURADO, P. Breeding bird assemblages in riparian galleries of the Guadiana River basin (Portugal): the effect of spatial structure and habitat variables. Ecological Research, v. 25, n. 2, p. 283-294, 2010.

GONÇALVES, E. D.; SOUZA, V. F. de. Direito à moradia: a possibilidade de regularização fundiária nas Áreas de Preservação Permanente. Direito e Práxis, v. 04, n. 01, p. 96-111, 2012.

SWANSON, F.J.; MCKEE, W.A.; CUMMINS, K.W. An ecosystem perspective of riparian zones. Focus on links between land and water. BioScience, v. 41, n. 8, p. 540-50, 1991.

GRIMM, N. B.; GROVE, J. M.; PICKETT, S. T. A.; REDMAN, C. L. Integrated Approaches to Long-Term Studies of Urban Ecological Systems: Urban ecological systems present multiple challenges to ecologists - pervasive human impact and extreme heterogeneity of cities, and the need to integrate social and ecological approaches, concepts, and theory. BioScience, v. 50, n. 7, p. 571 - 584, 2000. DOI: 10.1641/00063568(2000)050[0571:IATLTO]2.0.CO;2. 
HARPER, D. A. T.(ed.). Numerical Palaeobiology: Computer-based Modelling and Analysis of Fossils and their Distributions. New York: John Wiley \& Sons, 1999.

HUTYRA, L. R.; DUREN, R.; GURNEY, K. R.; GRIMM, N.; KORT, E. A.; LARSON, E.; SHRESTHA, G. Urbanization and the carbon cycle: Current capabilities and research outlook from the natural sciences perspective. Earth's Future, v. 2, p.473-495, 2014. DOI: $10.1002 / 2014 \mathrm{EF} 000255$.

INSTITUTO FLORESTAL/SP. Resultados. Mapas Municipais. SIFESP. Disponível em: <http://www.iflorestal.sp.gov.br/sifesp/mapasmunicipais.html>. Acesso em: 16 maio 2016.

KALE, M.; DUDHE, N.; KASAMBE, R. Impact of urbanization on avian population and its status in Maharashtra State, India. International Journal of Applied Environmental Sciences, v.7 n. 1, p. 59-76, 2012.

KENNEDY, C.M.; MARRA, P.P.; FAGAN, W.F.; NEEL, M.C. Landscape matrix and species traits mediate responses of Neotropical resident birds to forest fragmentation in Jamaica. Ecological Monographs, v. 80, p. 4, p. 651-669, 2010. DOI: 10.1890/09-0904.1

LEES, A. C.; PERES, C. A. Conservation Value of Remnant Riparian Forest Corridors of Varying Quality for Amazonian Birds and Mammals. Conservation Biology, v. 22, n. 2, p.439-449, 2008. DOI: 10.1111/j.1523-1739.2007.00870.x

LIDICKER Jr., W. Z. Responses of mammals to habitat edges: an overview. Landscape Ecology, v.14, n.4, p. 333-343, 1999. DOI: 10.1023/A:1008056817939.

LUTHER, D.; HILTY, J.; WEISS, J.; CORNWALL, C. Assessing the impact of local habitat variables and landscape context on riparian birds in agricultural, urbanized, and native landscapes. Biodiversity and Conservation, v. 17, p. 1923-1935, 2008. DOI: 10.1007/s10531-008-9332-5.

MAFIA, P. de O. Avifauna em fragmentos de mata ciliar e áreas adjacentes no baixo Rio Grande, Sudeste do Brasil. 2015. 110 f. Dissertação (Mestrado em Ecologia de Biomas Tropicais) - Universidade Federal de Ouro Preto: Ouro Preto, Minas Gerais, 2015.

MARINI, M. Â.; GARCIA, F. I. Conservação de aves no Brasil. Megadiversidade, v. 1, n. 1, jul. 2005.

MARZLUFF, J. M. (2001). Worldwide urbanization and its effects on birds. In Avian ecology and conservation in an urbanizing world (pp. 19-47). Springer, Boston, MA.

MCDONNELL, M. J.; PICKETT, S. T. A. Ecosystem Structure and Function along UrbanRural Gradients: An Unexploited Opportunity for Ecology. Ecology, v. 71, n. 4, p.1232 - 1237, 1990. DOI: $10.2307 / 1938259$

MCKINNEY, M. L. Urbanization, Biodiversity, and Conservation: The impacts of urbanization on native species are poorly studied, but educating a highly urbanized human population about these impacts can greatly improve species conservation in all ecosystems. $\begin{array}{lllll}\text { Bioscience, } & \text { v.52, } & \text { n. } 10, & 2002 . & \text { DOI: }\end{array}$ 3568(2002)052[0883:UBAC]2.0.CO;2.

MELLO, K.D.; PETRI, L.; LEITE, E.C.; TOPPA, R.H. Cenários ambientais para o ordenamento territorial de Áreas de Preservação Permanente no município de Sorocaba, SP. Revista Árvore, Viçosa-MG, v.38, n.2, p.309-317, 2014. DOI: 10.1590/S010067622014000200011 
METZGER, J. P. Does the forest code have a scientific base? Natureza \& Conservação, v.8, n.1, p.92-99, 2010.

NETO, R. M.; VIADANA, A. G. Abordagem biogeográfica sobre a fauna silvestre em áreas antropizadas: o sistema Atibaia-Jaguari em Americana (SP). Sociedade \& Natureza, Uberlândia, v. 18, n. 35, p. 5-21, dez. 2006.

ONEAL, A. S.; ROTENBERRY, J. T. Scale-dependent habitat relations of birds in riparian corridors in an urbanizing landscape. Landscape and Urban Planning, v. 92, p. 264275, 2009.

ORTEGA-ÁLVAREZ, R.; MACGREGOR-FORS, I. Dusting off the file: A review of knowledge on urban ornithology in Latin America. Landscape and Urban Planning, v. 101, p. 1-10, 2011.

Plaza, P.I.; Uhart, M.; Caselli, A.; Wiemeyer, G.; Lambertucci, S.A. A review of lead contamination in South American birds: The need for more research and policy changes. Perspectives in Ecology and Conservation, v.16, n.4, p.201-207, 2018.

PIACENTINI, V. DE Q.; ALEXANDRE, A.; AGNE, C. E.; MAURÍCIO, G. N.; PACHECO, J. F.; BRAVO, G. A.; BRITO, G. R. R.; NAKA, L. N.; OLMOS, F.; POSSO, S.; SILVEIRA, L. F.; BETINI, G. S.; CARRANO, E.; FRANZ, I.; LEES, A. C.; LIMA, L. M.; PIOLI, D.; SCHUNCK, F.; AMARAL, F. R. DO; BENCKE, G. A; COHN-HAFT, M.; FIGUEIREDO, L. F. A.; STRAUBE, F. C.; CESARI, E. Annotated checklist of the birds of Brazil by the Brazilian Ornithological Records Committee / Lista comentada das aves do Brasil pelo Comitê Brasileiro de Registros Ornitológicos. Revista Brasileira de Ornitologia, v. 23, n. 2, p. 91-298, jun. 2015.

PICKETT, S. T. A.; CADENASSO, M. L.; GROVE, J. M.; BOONE, C. G.; GROFFMAN, P. M.; IRWIN, E.; KAUSHAL, S. S.; MARSHALL, V.; MCGRAT, B. P.; NILON, C. H.; POUYAT, R. V.; SZLAVECZ, K.; TROY, A.; WARREN, P. Urban ecological systems: Scientific foundations and a decade of progress. Journal of Environmental Management, v.92, n.3, p.331-362, 2011. DOI: 10.1016/j.jenvman.2010.08.022

ROLIM, G. de S.; CAMARGO, M. B. P. DE; LANIA, D. G.; MORAES, J. F. L. de. Classificação climática de Köppen e de Thornthwaite e sua aplicabilidade na determinação de zonas agroclimáticas para o estado de São Paulo. Bragantia, Campinas, v.66, n.4, p. 711-720, 2007. DOI: 10.1590/S0006-87052007000400022.

ROSENBERG, D. K.; NOON, B. R.; MESLOW, E. C. Biological Corridors: Form, Function, and Efficacy. BioScience, v.47, n.10, p.677-687, 1997. DOI: 10.2307/1313208.

$\mathrm{SAAB}, \mathrm{V}$. Importance of spatial scale to habitat use by breeding birds in riparian forests: a hierarchical analysis. Ecological Applications, v. 9, n. 1, p.135-151, 1999. DOI: 10.1890/1051-0761(1999)009[0135:IOSSTH]2.0.CO;2.

SARASOLA, J.H. Raptor Species Index. Birds of Prey, p.499, 2018.

SCHERER, J. de F. M.; SCHERER, A. L.; PETRY, M. V. Estrutura trófica e ocupação de hábitat da avifauna de um parque urbano em Porto Alegre, Rio Grande do Sul, Brasil. Biotemas, v. 23, n. 1, p. 169-180, mar. 2010. DOI: 10.5007/2175-7925.2010v23n1p169.

SEAMAN, B. S.; SCHULZE, C. H. The importance of gallery forests in the tropical lowlands of Costa Rica for understorey forest birds. Biological Conservation, v. 143, p. 391-398, 2010. DOI: 10.1016/j.biocon.2009.11.002 
SECRETARIA DO MEIO AMBIENTE DO ESTADO DE SÃO PAULO (SMA/SP). Cadernos de Educação Ambiental. Matas Ciliares. 2. ed. 2014

SICK, H. Ornitologia Brasileira. Rio de Janeiro: Nova Fronteira, 1997.

SIGRIST, T. Guia de Campo Avis Brasilis: Avifauna Brasileira. 3. ed. Vinhedo: Avis Brasilis, 2013.

SILVA, W. R.; VIELLIARD, J. Avifauna de mata ciliar. In: RODRIGUES, R. R.; LEITÃO FILHO, H. de F. (Editor). Matas Ciliares: conservação e recuperação. São Paulo: Universidade de São Paulo, 2000. p. 169-85.

SMITH, R. J.; SCHAEFER, J.M. Avian characteristics of an urban riparian strip corridor. Wilson Bulletin, v. 104, p. 732-738, 1992.

SMITH, T.A.; OSMOND, D.L.; MOORMAN, C.E.; STUCKY, J.M.; GILLIAM, J.W. Effect of Vegetation Management on Bird Habitat in Riparian Buffer Zones. Southeastern Naturalist, v. 7 , n. 2, p. 277-288, 2008. DOI: 10.1656/15287092(2008)7[277:EOVMOB]2.0.CO;2

TELINO-JÚNIOR, W.R.; DIAS, M.M.; AZEVEDO-JÚNIOR, S.D.; LYRA-NEVES, R.M.; LARRAZÁBAL, M.E.L. Estrutura trófica da avifauna na Reserva Estadual de Gurjaú, Zona da Mata Sul, Pernambuco, Brasil. Revista Brasileira de Zoologia, v. 22 n. 4, p. 962-973, 2005. DOI: 10.1590/S0101-81752005000400024.

TOLEDO, M. C. B.; DONATELLI, R. J.; BATISTA, G. T. Relation between green spaces and bird community structure in an urban area in Southeast Brazil. Urban Ecosystems, v.15, n.1, p.111-131, 2012. DOI: 1007/s11252-011-0195-2

VALADÃO, R. M.; FRANCHIN, A. G.; MARÇAL JÚNIOR, O. A avifauna no Parque Municipal Victorio Siquierolli, zona urbana de Uberlândia (MG). Biotemas, v. 19, n. 1, p. 81-91, 2006. DOI: $10.5007 / \% 25 x$.

VAN RENSBURG, B. J.; PEACOCK, D. S.; ROBERTSON, M.P. Biotic homogenization and alien bird species along an urban gradient in South Africa. Landscape and Urban Planning, v.92, n.3, p.233-241, 2009. DOI: 10.1016/j.landurbplan.2009.05.002

VILlANUEVA, R. E. V.; SILVA, M. da. Organização Trófica da Avifauna do Campus da Universidade Federal de Santa Catarina (UFSC), Florianópolis, SC. Biotemas, v.9, n.2, p.57- 69, 1996.. DOI: 10.5007/\%25x.

WATSON, J. E. M.; WHITTAKER, R. J.; DAWSON, T. P. Habitat structure and proximity to forest edge affect the abundance and distribution of forest-dependent birds in tropical coastal forests of southeastern Madagascar. Biological Conservation, v. 120, p. 311-327, 2004. DOI: 10.1016/j.biocon.2004.03.004.

Wikiaves. 2017. Busca por sons. Retrieved on September 13, 2017, from www.wikiaves.com.br/buscasimples.php?tm=s.

WILLIS, E. O. The composition of avian communities in remanescent woodlots in southern Brazil. Papéis Avulsos de Zoologia, v. 33, n. 1, p. 1-25, 1979.

Xeno-Canto. 2017. Retrieved on September 13, 2017, from www.xeno-canto.org/.

YU, T.; GUO, Y. Effects of Urbanization on Bird Species Richness and Community Composition. Pakistan Journal of Zoology, v. 45, n. 1, p. 59-69, 2013. 
Appendix 1. List of species with scientific and common names; origin (native, $\mathrm{N}$, exotic, $\mathrm{E})$; trophic group $(\mathrm{G}=\mathrm{Granivore} ; \mathrm{F}=$ Frugivore; $\mathrm{H}=\mathrm{Herbivore}$; = insectivore; $\mathrm{N}=$ Nectarivore; $\mathrm{P}=$ Piscivore; $\mathrm{O}=$ Omnivorous; $\mathrm{C}=$ Carnivore; $\mathrm{Ne}=$ Scavenger $)$, habitat $(\mathrm{A}=$ arboreal; $\mathrm{Ef}=\mathrm{forest}$ edge; $\mathrm{Oa}=\mathrm{open}$ area; $\mathrm{W}=$ wetland; $\mathrm{C}=$ canopy); total abundance, relative abundance and frequency observed in riparian forest fragments in the municipalities of Aparecida, Potim and Guaratinguetá (SP).

\begin{tabular}{|c|c|c|c|c|c|c|}
\hline Family & Scientific Name/Common English Name & Origin & $\begin{array}{l}\text { Trophic } \\
\text { groups }\end{array}$ & Habitat & Total Abundance & $\begin{array}{l}\text { Relative } \\
\text { abundance }\end{array}$ \\
\hline ACCIPITRIDAE & Amadonastur lacernulatus (Temminck, 1827) White-necked Hawk & $\mathrm{N}$ & $\mathrm{C}$ & A & 1 & 0.001 \\
\hline ACCIPITRIDAE & Rupornis magnirostris (Gmelin, 1788) Roadside Hawk & $\mathrm{N}$ & $\mathrm{C}$ & Oc & 3 & 0.002 \\
\hline ALCEDINIDAE & Megaceryle torquata (Linnaeus, 1766) Ringed Kingfisher & $\mathrm{N}$ & $\mathrm{P}$ & $\mathrm{W}$ & 4 & 0.003 \\
\hline ANHINGIDAE & Anhinga anhinga (Linnaeus, 1766) Anhinga & $\mathrm{N}$ & $\mathrm{P}$ & $\mathrm{W}$ & 1 & 0.001 \\
\hline ARDEIDAE & Ardea alba Linnaeus, 1758 Great Egret & $\mathrm{N}$ & $\mathrm{O}$ & $\mathrm{W}$ & 2 & 0.001 \\
\hline ARDEIDAE & Ardea cocoi Linnaeus, 1766 Cocoi Heron & $\mathrm{N}$ & $\mathrm{P}$ & $\mathrm{W}$ & 1 & 0.001 \\
\hline ARDEIDAE & Butorides striata (Linnaeus, 1758) Striated Heron & $\mathrm{N}$ & $\mathrm{P}$ & $\mathrm{W}$ & 2 & 0.001 \\
\hline ARDEIDAE & Nycticorax nycticorax (Linnaeus, 1758) Black-crowned Night-Heron & $\mathrm{N}$ & $\mathrm{O}$ & $\mathrm{W}$ & 1 & 0.001 \\
\hline CATHARTIDAE & Coragyps atratus (Bechstein, 1793) Black Vulture & $\mathrm{N}$ & $\mathrm{S}$ & Oc & 9 & 0.006 \\
\hline COLUMBIDAE & Columbina talpacoti (Temminck, 1811) Ruddy Ground-Dove & $\mathrm{N}$ & $\mathrm{G}$ & $\mathrm{Oa} / \mathrm{Ef}$ & 9 & 0.006 \\
\hline COLUMBIDAE & Leptotila verreauxi Bonaparte, 1855 White-tipped Dove & $\mathrm{N}$ & $\mathrm{G} / \mathrm{F}$ & Ef & 30 & 0.021 \\
\hline COLUMBIDAE & Patagioenas picazuro (Temminck, 1813) Picazuro Pigeon & $\mathrm{N}$ & $\mathrm{G} / \mathrm{F}$ & Ef & 18 & 0.013 \\
\hline CUCULIDAE & Crotophaga ani Linnaeus, 1758 Smooth-billed Ani & $\mathrm{N}$ & $\mathrm{C}$ & $\mathrm{Oa}$ & 20 & 0.014 \\
\hline CUCULIDAE & Guira guira (Gmelin, 1788) Guira Cuckoo & $\mathrm{N}$ & $\mathrm{C}$ & $\mathrm{Oa}$ & 5 & 0.004 \\
\hline CUCULIDAE & Piaya cayana (Linnaeus, 1766) Squirrel Cuckoo & $\mathrm{N}$ & $\mathrm{I}$ & A & 14 & 0.01 \\
\hline CUCULIDAE & Tapera naevia (Linnaeus, 1766) Striped Cuckoo & $\mathrm{N}$ & I & Ef & 8 & 0.006 \\
\hline DENDROCOLAPTIDAE & Lepidocolaptes angustirostris (Vieillot, 1818) Narrow-billed Woodcreeper & $\mathrm{N}$ & I & $\mathrm{Oa}$ & 5 & 0.004 \\
\hline DONACOBIIDAE & Donacobius atricapilla (Linnaeus, 1766) Black-capped Donacobius & $\mathrm{N}$ & I & W & 1 & 0.001 \\
\hline FALCONIDAE & Caracara plancus (Miller, 1777) Southern Caracara & $\mathrm{N}$ & $\mathrm{O}$ & $\mathrm{Oc} / \mathrm{Oa}$ & 6 & 0.004 \\
\hline FALCONIDAE & Milvago chimachima (Vieillot, 1816) Yellow-headed Caracara & $\mathrm{N}$ & $\mathrm{O}$ & Oc & 2 & 0.001 \\
\hline FRINGILLIDAE & Euphonia chlorotica (Linnaeus, 1766) Purple-throated Euphonia & $\mathrm{N}$ & $\mathrm{F}$ & A & 24 & 0.017 \\
\hline FURNARIIDAE & Certhiaxis cinnamomeus (Gmelin, 1788) Yellow-chinned Spinetail & $\mathrm{N}$ & I & $\mathrm{W}$ & 33 & 0.024 \\
\hline FURNARIIDAE & Furnarius figulus (Lichtenstein, 1823) Wing-banded Hornero & $\mathrm{N}$ & I & $\mathrm{W}$ & 17 & 0.012 \\
\hline FURNARIIDAE & Phacellodomus erythrophthalmus (Wied, 1821) Orange-eyed Thornbird & $\mathrm{N}$ & I & A & 10 & 0.007 \\
\hline FURNARIIDAE & Synallaxis spixi Sclater, 1856 Spix's Spinetail & $\mathrm{N}$ & I & A & 59 & 0.042 \\
\hline HIRUNDINIDAE & Alopochelidon fucata (Temminck, 1822) Tawny-headed Swallow & $\mathrm{N}$ & $\mathrm{I} / \mathrm{F}$ & $\mathrm{Oa}$ & 1 & 0.001 \\
\hline HIRUNDINIDAE & Pygochelidon cyanoleuca (Vieillot, 1817) Blue-and-white Swallow & $\mathrm{N}$ & $\mathrm{I}$ & Oc & 140 & 0.1 \\
\hline HIRUNDINIDAE & Tachycineta albiventer (Boddaert, 1783) White-winged Swallow & $\mathrm{N}$ & I & $\mathrm{W}$ & 3 & 0.002 \\
\hline ICTERIDAE & Chrysomus ruficapillus (Vieillot, 1819) Chestnut-capped Blackbird & $\mathrm{N}$ & $\mathrm{G} / \mathrm{F}$ & $\mathrm{W}$ & 2 & 0.001 \\
\hline MOTACILLIDAE & Anthus lutescens Pucheran, 1855 Yellowish Pipit & $\mathrm{N}$ & I & $\mathrm{Oa}$ & 4 & 0.003 \\
\hline PARULIDAE & Setophaga pitiayumi (Vieillot, 1817) Tropical Parula & $\mathrm{N}$ & I & A & 2 & 0.001 \\
\hline PARULIDAE & Geothlypis aequinoctialis (Gmelin, 1789) Masked Yellowthroat & $\mathrm{N}$ & I & A & 5 & 0.004 \\
\hline
\end{tabular}

Rev. Ambient. Água vol. 7 (supplement) - Taubaté 2019 


\begin{tabular}{|c|c|c|c|c|c|c|}
\hline Continued... & & & & & & \\
\hline PASSERIDAE & Passer domesticus (Linnaeus, 1758) House Sparrow & $\mathrm{E}$ & $\mathrm{O}$ & Ef & 2 & 0.001 \\
\hline PHALACROCORACIDAE & Phalacrocorax brasilianus (Gmelin, 1789) Neotropic Cormorant & $\mathrm{N}$ & $\mathrm{P}$ & $\mathrm{W}$ & 5 & 0.004 \\
\hline PICIDAE & Celeus flavescens (Gmelin, 1788) Blond-crested Woodpecker & $\mathrm{N}$ & $\mathrm{O}$ & A & 4 & 0.003 \\
\hline PICIDAE & Colaptes campestris (Vieillot, 1818) Campo Flicker & $\mathrm{N}$ & I & $\mathrm{Oa}$ & 4 & 0.003 \\
\hline PICIDAE & Colaptes melanochloros (Gmelin, 1788) Green-barred Woodpecker & $\mathrm{N}$ & I & Ef & 1 & 0.001 \\
\hline PICIDAE & Melanerpes candidus (Otto, 1796) White Woodpecker & $\mathrm{N}$ & $\mathrm{I} / \mathrm{F}$ & $\mathrm{Oa}$ & 3 & 0.002 \\
\hline PICIDAE & Picumnus cirratus Temminck, 1825 White-barred Piculet & $\mathrm{N}$ & I & A & 38 & 0.027 \\
\hline PICIDAE & Veniliornis spilogaster (Wagler, 1827) White-spotted Woodpecker & $\mathrm{N}$ & $\mathrm{I}$ & Ef & 7 & 0.005 \\
\hline PIPRIDAE & Manacus manacus (Linnaeus, 1766) White-bearded Manakin & $\mathrm{N}$ & $\mathrm{F} / \mathrm{I}$ & A & 2 & 0.001 \\
\hline PSITTACIDAE & Forpus xanthopterygius (Spix, 1824) Blue-winged Parrotlet & $\mathrm{N}$ & $\mathrm{F} / \mathrm{G}$ & A & 28 & 0.02 \\
\hline PSITTACIDAE & Psittacara leucophthalmus (Statius Muller, 1776) White-eyed Parakeet & $\mathrm{N}$ & $\mathrm{F} / \mathrm{G}$ & $\mathrm{Oc}$ & 22 & 0.016 \\
\hline RALLIDAE & Aramides saracura (Spix, 1825) Slaty-breasted Wood-Rail & $\mathrm{N}$ & $\mathrm{O}$ & $\mathrm{W}$ & 2 & 0.001 \\
\hline RALLIDAE & Gallinula galeata (Lichtenstei, 1818) Common Gallinule & $\mathrm{N}$ & $\mathrm{H}$ & $\mathrm{W}$ & 2 & 0.001 \\
\hline RAMPHASTIDAE & Ramphastos toco Statius Muller, 1776 Toco Toucan & $\mathrm{N}$ & $\mathrm{O}$ & $\mathrm{Oc}$ & 1 & 0.001 \\
\hline RHYNCHOCYCLIDAE & Hemitriccus nidipendulus (Wied, 1831) Hangnest Tody-Tyrant & $\mathrm{N}$ & I & A & 5 & 0.004 \\
\hline RHYNCHOCYCLIDAE & Todirostrum cinereum (Linnaeus, 1766) Common Tody-Flycatcher & $\mathrm{N}$ & I & A & 51 & 0.036 \\
\hline THAMNOPHILIDAE & Thamnophilus caerulescens Vieillot, 1816 Variable Antshrike & $\mathrm{N}$ & I & A & 6 & 0.004 \\
\hline THRAUPIDAE & Coereba flaveola (Linnaeus, 1758) Bananaquit & $\mathrm{N}$ & $\mathrm{N} / \mathrm{F}$ & A & 109 & 0.078 \\
\hline THRAUPIDAE & Conirostrum speciosum (Temminck, 1824) Chestnut-vented Conebill & $\mathrm{N}$ & I & A & 14 & 0.01 \\
\hline THRAUPIDAE & Ramphocelus bresilius (Linnaeus, 1766) Brazilian Tanager & $\mathrm{N}$ & $\mathrm{F}$ & A & 53 & 0.038 \\
\hline THRAUPIDAE & Saltator similis d'Orbigny \& Lafresnaye, 1837 Green-winged Saltator & $\mathrm{N}$ & $\mathrm{O}$ & Ef & 15 & 0.011 \\
\hline THRAUPIDAE & Tangara palmarum (Wied, 1823) Palm Tanager & $\mathrm{N}$ & $\mathrm{F} / \mathrm{I}$ & A & 8 & 0.006 \\
\hline THRAUPIDAE & Tangara sayaca (Linnaeus, 1766) Sayaca Tanager & $\mathrm{N}$ & $\mathrm{F} / \mathrm{I}$ & A & 54 & 0.039 \\
\hline THRAUPIDAE & Tersina viridis (Illiger, 1811) Swallow Tanager & $\mathrm{N}$ & $\mathrm{F} / \mathrm{I}$ & A & 2 & 0.001 \\
\hline THRAUPIDAE & Thlypopsis sordida (d'Orbigny \& Lafresnaye, 1837) Orange-headed Tanager & $\mathrm{N}$ & $\mathrm{F} / \mathrm{I}$ & A & 29 & 0.021 \\
\hline THRAUPIDAE & Volatinia jacarina (Linnaeus, 1766) Blue-black Grassquit & $\mathrm{N}$ & $\mathrm{G}$ & $\mathrm{Oa}$ & 3 & 0.002 \\
\hline THRESKIORNITHIDAE & Mesembrinibis cayennensis (Gmelin, 1789) Green Ibis & $\mathrm{N}$ & I & A & 6 & 0.004 \\
\hline TITYRIDAE & Pachyramphus polychopterus (Vieillot, 1818) White-winged Becard & $\mathrm{N}$ & I & A & 2 & 0.001 \\
\hline TROCHILIDAE & Eupetomena macroura (Gmelin, 1788) Swallow-tailed Hummingbird & $\mathrm{N}$ & $\mathrm{N}$ & Ef & 2 & 0.001 \\
\hline TROCHILIDAE & Chlorostilbon lucidus (Shaw, 1812) Glittering-bellied Emerald & $\mathrm{N}$ & $\mathrm{N}$ & Ef & 10 & 0.007 \\
\hline TROCHILIDAE & Florisuga fusca (Vieillot, 1817) Black Jacobin & $\mathrm{N}$ & $\mathrm{N}$ & Ef & 7 & 0.005 \\
\hline TROGLODYTIDAE & Troglodytes musculus Naumann, 1823 Southern House Wren & $\mathrm{N}$ & I & $\mathrm{Ef}$ & 76 & 0.054 \\
\hline TURDIDAE & Turdus amaurochalinus Cabanis, 1850 Creamy-bellied Thrush & $\mathrm{N}$ & $\mathrm{I} / \mathrm{F}$ & A & 1 & 0.001 \\
\hline TURDIDAE & Turdus leucomelas Vieillot, 1818 Pale-breasted Thrush & $\mathrm{N}$ & $\mathrm{I} / \mathrm{F}$ & A & 38 & 0.027 \\
\hline TYRANNIDAE & Arundinicola leucocephala (Linnaeus, 1764) White-headed Marsh Tyrant & $\mathrm{N}$ & I & $\mathrm{W}$ & 1 & 0.001 \\
\hline TYRANNIDAE & Camptostoma obsoletum (Temminck, 1824) Southern Beardless-Tyrannulet & $\mathrm{N}$ & $\mathrm{I} / \mathrm{F}$ & A & 56 & 0.04 \\
\hline TYRANNIDAE & Elaenia flavogaster (Thunberg, 1822) Yellow-bellied Elaenia & $\mathrm{N}$ & $\mathrm{I} / \mathrm{F}$ & A & 6 & 0.004 \\
\hline
\end{tabular}




\begin{tabular}{|c|c|c|c|c|c|c|}
\hline Continued... & & & & & & \\
\hline TYRANNIDAE & Elaenia spectabilis Pelzeln, 1868 Large Elaenia & $\mathrm{N}$ & $\mathrm{I} / \mathrm{F}$ & A & 11 & 0.008 \\
\hline TYRANNIDAE & Fluvicola nengeta (Linnaeus, 1766) Masked Water-Tyrant & $\mathrm{N}$ & I & $\mathrm{W}$ & 17 & 0.012 \\
\hline TYRANNIDAE & Lathrotriccus euleri (Cabanis, 1868) Euler's Flycatcher & $\mathrm{N}$ & I & A & 15 & 0.011 \\
\hline TYRANNIDAE & Megarynchus pitangua (Linnaeus, 1766) Boat-billed Flycatcher & $\mathrm{N}$ & $\mathrm{O}$ & Oc & 21 & 0.015 \\
\hline TYRANNIDAE & Myiophobus fasciatus (Statius Muller, 1776) Bran-colored Flycatcher & $\mathrm{N}$ & I & A & 38 & 0.027 \\
\hline TYRANNIDAE & Myiodynastes maculatus (Statius Muller, 1776) Streaked Flycatcher & $\mathrm{N}$ & $\mathrm{I} / \mathrm{F}$ & A & 7 & 0.005 \\
\hline TYRANNIDAE & Myiozetetes similis (Spix, 1825) Social Flycatcher & $\mathrm{N}$ & $\mathrm{I} / \mathrm{F}$ & $\mathrm{W}$ & 21 & 0.015 \\
\hline TYRANNIDAE & Myiarchus swainsoni Cabanis \& Heine, 1859 Swainson's Flycatcher & $\mathrm{N}$ & $\mathrm{I} / \mathrm{F}$ & A & 1 & 0.001 \\
\hline TYRANNIDAE & Phyllomyias fasciatus (Thunberg, 1822) Planalto Tyrannulet & $\mathrm{N}$ & I & A & 4 & 0.003 \\
\hline TYRANNIDAE & Pitangus sulphuratus (Linnaeus, 1766) Great Kiskadee & $\mathrm{N}$ & $\mathrm{O}$ & $\mathrm{Oc}$ & 92 & 0.066 \\
\hline TYRANNIDAE & Satrapa icterophrys (Vieillot, 1818) Yellow-browed Tyrant & $\mathrm{N}$ & I & $\mathrm{Oa}$ & 1 & 0.001 \\
\hline TYRANNIDAE & Serpophaga nigricans (Vieillot, 1817) Sooty Tyrannulet & $\mathrm{N}$ & I & $\mathrm{W}$ & 1 & 0.001 \\
\hline TYRANNIDAE & Serpophaga subcristata (Vieillot, 1817) White-crested Tyrannulet & $\mathrm{N}$ & I & A & 15 & 0.011 \\
\hline TYRANNIDAE & Sirystes sibilator (Vieillot, 1818) Sibilant Sirystes & $\mathrm{N}$ & I & Ef & 1 & 0.001 \\
\hline TYRANNIDAE & Tyrannus melancholicus Vieillot, 1819 Tropical Kingbird & $\mathrm{N}$ & I & Ef & 12 & 0.009 \\
\hline TYRANNIDAE & Tyrannus savana Vieillot, 1808 Fork-tailed Flycatcher & $\mathrm{N}$ & I & $\mathrm{Oc} / \mathrm{Oa}$ & 1 & 0.001 \\
\hline VIREONIDAE & Vireo chivi (Vieillot, 1817) Chivi Vireo & $\mathrm{N}$ & I & A & 21 & 0.015 \\
\hline XENOPIDAE & Xenops rutilans Temminck, 1821 Streaked Xenops & $\mathrm{N}$ & I & A & 4 & 0.003 \\
\hline Total & & & & \multicolumn{3}{|c|}{1,400} \\
\hline
\end{tabular}

Rev. Ambient. Água vol. 7 (supplement) - Taubaté 2019 